\section{In the name of science: the conceptual and ideological background of Charles Richet's eugenics}

\author{
Em nome da ciência: \\ o contexto conceitual e \\ ideológico da eugenia de \\ Charles Richet
}

Antonello La Vergata

Professor, Dipartimento di Studi Linguistici e Culturali/Università di Modena e Reggio Emilia.

Modena - Emilia-Romagna - Italy

alavergata@unimore.it

Received on 20 Jul. 2017.

Approved on 17 Jan. 2018.
LA VERGATA, Antonello. In the name of science: the conceptual and ideological background of Charles Richet's eugenics. História, Ciências, Saúde - Manguinhos, Rio de Janeiro, v.25, supl., ago. 2018, p.125-144.

\section{Abstract}

The French physiologist and Nobel Prize winner Charles Richet was the author of an impressive quantity of writings, including novels and poetry. He was an out-and-out eugenicist, convinced that "intentional, conscious, scientific, and methodical" selection could achieve "any result, provided we have enough patience." He believed that the quantitative and qualitative growth of the population was of vital importance for France. In La sélection humaine (1919) and other writings, he dreamt of conscious selection to create "intellectual élites." This process would be crowned by the production of a "higher human nature, a real surhumanité." A staunch believer in the inheritance of acquired characteristics, Richet combined Darwinism and Lamarckism.

Keywords: eugenics; France; racism; Lamarckism; Charles Richet (1850-1935).

Resumo

O fisiologista e vencedor do prêmio Nobel Charles Richet foi autor de numerosos escritos, incluindo romances e poesia. Eugenicista meticuloso, estava convencido de que uma seleção "intencional, conscienciosa, científica e metodológica" podeira atingir "qualquer resultado, contanto que tivéssemos paciência". Ele acreditava que o crescimento quantitativo e qualitativo da população tinha importância vital para a França. Em La sélection humaine (1919) e em outros escritos, ele sonhava com uma seleção consciente criando "elites intelectuais". Esse processo culminaria com a produção de uma "natureza humana superior, uma superhumanidade". Crente aguerrido da herança de caracteres hereditários, Richet combinou darwinismo e lamarckismo.

Palavras-chave: eugenia; França; racismo; lamarckismo; Charles Richet (1850-1935). 


\section{In the name of science (and oneself)}

Charles Richet (1850-1935), a professor of physiology at the University of Paris, winner of the 1913 Nobel Prize for medicine for his research on anaphylaxis (a term he himself coined), and a pioneer of serotherapy, was a man of multifarious interests. A copious writer, he poured out volume upon volume on a range of issues, as if prompted by an inner urge verging on graphomany, until the end of his life. These texts ranged from experimental work (Wolf, 2002) to a ten-volume Dictionnaire de physiologie (which he edited and completed in 1928), writings on philosophy, history, psychology, sociology, pacifism and international arbitration, novels (under the pseudonym of Charles Epheyre), fairy tales, verse, and works for the theatre (a 1901 play, Circé, was performed by the legendary actress Sarah Bernard). For a while he was also interested in aviation, and to this field he contributed some technical innovations and established the first French aeronautic enterprise with the Breguet brothers (Richet, 1901, 1933b; Béjin, 1996). In 1919 he published La sélection humaine (written in 1912), in which he endorsed an extreme form of eugenics he considered an integral part of his work as a scientist. He was convinced that it was society's duty "to give science, and consequently scientists, absolute predominance within the State" ${ }^{11}$ (Richet, 1930, p.217) since they were "absolutely honest..., disinterested, laborious, loyal, proud, independent" and, in short, "the highest ideal type of mankind" (Richet, 1923, p.18-19, 79). It is no wonder he felt authorised to speak in the name of science.

Not everything that Richet wrote on subjects which are not strictly physiological is very original. It was not necessary to be a famous scientist to say most of what he said. However, his writings provide elements which are interesting to understand a particular cultural context. The aim of this article is to present some aspects of his copious production which are less well known than his eugenics, and to show that they were knit together within an ideological framework: ideological not in the political sense of the word, but rather an aggregate of (mostly tacit) assumptions, cultural biases, opinions, and "prejudices" taken for granted uncritically which as part and parcel of Richet's discourse heavily influenced his pronouncements on eugenics as well as on Darwinism, Lamarckism, teleology, race, education, hygiene, and society. My overall focus is not so much Richet's eugenics as its conceptual background. I do not attempt to situate him within the spectrum of French opinions on strictly political matters or issues such as gender, masculinity, and femininity (Frader, 2008; Koos, 1996, 2009, 2014; Read, 2008, 2012, 2014a, 2014b). There are three reasons for this. First, discussing these issues would require a much longer and quite different article. Second, comparison between Richet and authors such as Adolphe Pinard, Eugène Apert, Georges Schreiber, Justin Sicard de Plauzolles, Charles Binet-Sanglé, or Edouard Toulouse (as well as their critics) has been made by Carol (1995) and Schneider (1982, 1986, 1990, 2002). A growing literature on eugenics, social Darwinism and related issues in France (for instance Clark, 1984; Bellomy, 1984; Béjin, 1992; Carol, 1995; Bernardini, 1997; Drouard, 1998; Reggiani, 2007; Mucchielli, 2006; Read, 2008, 2012, 2014a, 2014b; Camiscioli, 2009; Turda, Gillette, 2014), makes it clear that it is mistaken to discuss it as a homogeneous phenomenon. Finally, an author must be thoroughly known before any serious attempt to classify him, and Richet (apart from his eugenics) is more quoted than 
known. Other scholars, who are better versed in French political debates than I, will see to this. It will not be an easy task, as Richet's "politics" were generic, confused, and wavering on practical applications.

\section{Hopeful forecasts, gloomy diagnoses, and public engagement}

In 1892 Richet published Dans cent ans, a book predicting the future of mankind over the next hundred years. These predictions covered a wide range of subjects: agriculture, industry, trade, population growth, technology, international politics, the arts, literature, science. War would disappear, democracy tending towards a socialism of sorts would spread throughout Europe and the US, "barbarous" (that is, all) Africans would be subjected to white domination or protectorates, Asia would be carved up by France, England and Russia, and so on. Curiously, not all the sciences would make substantial progress. Some of them (for instance, chemistry, thermodynamics, natural history, palaeontology, and microbiology) had somehow exhausted their potential for finding anything really new: "their way forward is already mapped out, and the results are foreseen." Later (Richet, 1927, p.98), Richet went as far as to point out as an instance of credulity the belief that the "theory of amino-acids" had a great future ahead. In return, progress in "the experimental side of natural sciences" was "virtually unlimited" (Richet, 1892, p.207, 213). We cannot create life, but we can transform plants and animals almost to the point of recreation, because living nature is "plastic" and "docile," as demonstrated by the success of breeders and horticulturalists. Richet stated that the study of inheritance and selection would reverberate in man himself, as we shall be obliged to "apply breeding to man" if we want him to make progress, because natural selection no longer operates in civilised societies. As a remedy we must establish "a sort of artificial selection" in an attempt to "make men stronger, more beautiful and more intelligent" (p.214, 216). "Who knows," said Richet, "whether by modifying the body and the soul of man through a selection both prudent and bold, we cannot eventually create beings far superior to what we now are?" (p.249). It is interesting to note that this came immediately after he asked whether future mankind, who dominated matter and better understood the cosmos, would be able to communicate with extra-terrestrial beings and, having discovered "new faculties" in ourselves, "with new worlds intermingled (mêlés) with the one which is familiar to us" (p.249). In 1891 Richet, who also invented the term "ectoplasm," founded the Annales des Sciences Psychiques, on the model of the British Society for Psychical Research (1882). He wrote extensively on telepathy, thought-transference, mediumship, and other paranormal phenomena (Richet, 1922b, 1928, 1931). His interest in these subjects never faltered; he considered them a natural continuation of his scientific activity (Osty, 1936).

Richet's predictions were not only an exercise in a genre which he liked to practice throughout his life. They were also an optimistic answer to many of his fellow countrymen's gloomy forecasts based on the fear of dépopulation, that is, the declining birth rate (Richet, 1891). The national census showed that, except for a period of stability between 1880 and 1890 , the birth rate had been decreasing continuously since 1794 . This was also a matter for concern in other European countries, especially colonial rivals, but in France, dépopulation 
became a source of national anxiety, particularly in nationalist and militarist circles, which were haunted by the desire for revanche after defeat in the Franco-German war of 1870-1871. As a pro-natalist manifesto stated, "Each time two future soldiers are born in France, five are born in Germany" (Ronsin, 1980, p.130). Reproduction was consequently a patriotic duty, and birth control was morally unacceptable and anti-national. One might recall Zola's novel Fécondité (1899), which from beginning to end was a plea for virtuous reproduction by the sane elements of a France in need of regeneration, and an attack on contraceptive practices. In 1896 Richet was one of the founders of the Alliance Nationale pour l'Accroissement de la Population Française (later the Alliance Nationale contre la Dépopulation), along with the journalist André Honnorat, the physician Emile Chaval, and the statistician Jacques Bertillon (Béjin, 1990). It is interesting to note that in that same year, the Ligue de Régénération Humaine was founded by the libertarian educationalist and militant neo-Malthusian Paul Robin to promote, as stated in the title of the Ligue's review, a "génération consciente."

Richet's pro-natalism never faltered. As late as 1930 he wrote: "We cannot let France perish for a lack of Frenchmen" (Richet, 1930, p.218). Nor did he ever doubt that the French were "the nation endowed with the most refined intelligence" (Richet, 1927, p.52). In spite of his scientific internationalism (depicted below) and his statement that "the world tends to unity" (Richet, 1892, p.97), he did not care about population problems in other nations, let alone non-white races: they had contributed nothing to civilisation, and would always remain inferior. He was adamant: "We owe our love to the beings that are near to us, and the nearer the more, more to a Frenchman than to a Chinese" (Richet, 1884, p.421). One hundred thousand French people were much worthy than one million non-whites. Therefore, "the growth of the French population is of the utmost importance for France, but for France alone. From a world perspective, it does not matter much whether there are one or six billion people on the earth" (Richet, 1919a, p.166-167). These words raise doubts about his inclination to consider all sides of the problem.

\section{Patriotism and pacifism}

Richet's patriotism did not include support for militarism. A staunch republican and non-believer, during the famous affaire Dreyfus he supported the innocence of the Jewish captain sentenced for felony and opposed the nationalist, militarist, clerical, and anti-Semitic party. A convinced pacifist, he was president of the Sociéte Française pour l'Arbitrage International, founded by Frédéric Passy in 1867, and pleaded for international arbitration in a number of books and articles. His Le passé de la guerre et l'avenir de la paix (Richet, 1907a) was translated into German in 1909 by the Austrian Baroness and pacifist Bertha von Suttner, who was awarded the Nobel Peace Prize in 1905. Richet considered war a "residue of barbarism," and a folly too enormous for mankind not to perceive eventually. It was doomed to disappear, if for no other reason than its increasing destructiveness: "By becoming ever more perfect, war will eventually become useless ... Peace is not an utopia, but a certainty." It was not "if" but "when" that was uncertain (Richet, 1892, p.59-62, 63; 1899). Far from a natural and beneficial phenomenon, a form of selection that favoured 
the development of civilisation (as mass psychologist Gustave Le Bon and others in France and abroad asserted), war was an absurd human invention (Le Bon, 1889; Richet, 1894). The belief that war was rooted in the psychological constitution of man had no scientific basis: there was nothing natural in such "enormous civilised (policées) machines" as armies, and "the constitution of human societies has its goal in remedying the iniquities of the state of nature." Military superiority did not mean moral superiority (Richet, 1905, p.4, 44, 50; cf. Richet, 1907a, 1919b). The road to peace passed through international law and the spread of scientific spirit, for science was peaceful in itself, pursuing "union instead of struggle, cooperation in common work instead of destructive tearing" (Richet, 1913, p.15). Peace and science went hand in hand: "Science and peace: that is happiness"2 (Richet, 1935, p.59). The draft caused a "reverse selection" by exposing the best of men to diseases, vice, fatigue and death, leaving the worst to undisturbed procreation (Richet, 1907a, p.87-88). This argument had been and would be used by many others (vom Brocke, 1984; Crook, 1994, p.119-129; Turda, 2009; La Vergata, 2015a, 2015b). Surely it did not make sense for an institution to turn down an individual unable to carry a heavy load but not care at all if he passed these poorer qualities on to his offspring (Richet, 1913, p.137; 1916, p.154).

Richet's pacifism did not prevent him from joining the vast army of French intellectuals who wrote thousands of pages blaming Germany for the First World War (Richet, 1916). The experience of this catastrophe led him to revise his former optimism. In 1919 he published L'homme stupide (Richet, 1919c) and in his last book he defined man as "the most anti-social animal in creation" (Richet, 1933a, p.117, 132), since his "fearsome warlike instincts, which are due to a long inheritance, animal and human," nourish "a disorderly love for fight." ${ }^{3}$ He supported the Society of Nations. Yet he did not approve of conscientious objection, for national independence is "the most sacred of things", which must therefore be defended. But he added that he did not know whether, as a judge, he would condemn a newspaper supporting conscientious objection: it all "depends on how the case would be presented." Luckily, he wrote, "all Frenchmen are pacifists." But they should beware of assurances by the "new Assyrian king" Hitler and Stalin, and "be on the lookout" (Richet, 1935, p.17, 29, 89-90). This warning did not apply to Mussolini, who in "overthrowing the old parliamentary system, has imposed on generous Italy his intelligent and at times fertile autocracy:" his dictatorship was "neither so ferocious as that of Stalin, nor so inept as that of Hitler." However, "far from wanting to pronounce his eulogy," Richet exhorted Mussolini to "read Roman history:" the Tarpeian rock was not distant from the Capitol (p.17, 22-23).

\section{Human selection}

According to Richet, modern civilisation was the very opposite of natural life. It "perverted natural selection, and sexual selection even more." The result was "degradation, deterioration, degeneration and bastardisation." The most intelligent triumphed in the "social conflict" but unfortunately were often the most vicious and sickly, (Richet, 1919a, p.19) and intelligence was to no avail without physical health and vigour (Richet, 1922a, p.45). Artificial selection was therefore necessary to remedy the "separation of bodily and mental qualities." Richet was vice-president of the Société Française d’Eugénique (founded 
in 1912), and in La sélection humaine he proved as outspoken a eugenicist as anyone could be: "I shall be called a monster," he wrote, "because I prefer healthy children to tainted ones," but "after much hesitation" he could not refrain from proffering his proposals for reform. They were, he conceded, "very bold," but "so logical" that any reader would be convinced (Richet, 1919a, p.163).

A control committee "more severe than the present conscription board" should examine the population in order to prevent racial miscegenation, suppress "abnormal" newborns, sterilise those who escaped this first selection, or, more realistically (since there was no chance "heroic means" would be adopted), forbid their marriage. It would also use exercise and other appropriate practices to develop the "brain skills" and bodily health of the population, encourage selective marriages in order to shape "aristocracies free from commoner's blood," "special intellectual élites," both "homogeneous" and "closed," which would protect their integrity by "eliminating those among their children that were lacking eminence." This would create "the cité of artists, the cité of mathematicians, the cité of musicians," each of these "keeping clear of others on the planet" (Richet, 1919a, p.180, 220-221, 214, 230). Curious for one who in the same book had railed in the name of nature against "ridiculous artificial distinctions" in society (p.59-60). Like other (French and non-French) eugenicists, Richet believed that monogamy was counter-selective and should ultimately disappear (Carol, 1995, p.202-204).

"If," Richet (1919a, p.166) said coldly, "we were to suppress legless cripples (culs-de-jatte), harelips, cleft foot, polydactyls, hydrocephalics, idiots, deaf mutes, those with rickets, cretins, human societies would lose nothing." He expanded this list of the abnormal in other writings to include epileptics, alcoholics, neurastenics (or neuropathics), degenerates, criminals, the scrofulous, hunchbacks, consumptives, lunatics, the ugly (laids) - or, to be more exact, "those whose ugliness exceeds the average of very ugly people" (Richet, 1922a, p.47) - the "vicious," onanists and others addicted to unnatural behaviours, procurers, the misshapen, cancer victims (cancéreux), the impotent, syphilitics, "aberrants," dwarfs, people born blind, lepers, and those who had been sentenced repeatedly (evidence of inborn criminality). Liars and "those who rebelled against any form of discipline" did not fare any better. Even the "lazy, either for want of will or physiological constitution," and "those unable to write, read and count" should be prevented from marrying (Richet, 1919a, p.176, 207; 1922a, p.47, 52; 1930, p.152; see also the full, blood-curdling list compiled by Carol, 1995, p.147-148). He referred to all these variously as "mere sketches of humankind," "larval forms," "tainted germs," "bad human stuff," "the shame of the species," "nasty spawn," a mere "mass of human flesh without human intelligence, ... bad living matter which is worth neither respect nor pity," but is protected by a "scandalous tolerance" and a "whiny philanthropy" (Richet, 1919a, p.164; 1922a, p.52). He never established a hierarchy of severity in order to decide what to deal with first. Despite denouncing the separation of bodily and mental qualities, time and time again he repeated that promoting "intelligence" was first and foremost, as "the development of intelligence is the essential element of human progress" (Richet, 1930, p.155). And "not going forward equals going backward," all the more so because "taints are transmitted more easily than virtues" (Richet, 1922a, p.53). 
Richet's opinions on how to develop intelligence differed from those which were current in France at the time. For instance, he attacked the "fetishism of public education." It was vital to develop intelligence in les gens du peuple, but for quite different reasons from those usually alleged: "if the intellectual élite allowed the mass of the population to sleep in the vacuum of ignorance, the élite would be overwhelmed by the ignorant mass" in a "brutish" and "baleful" invasion. What was important was not what one studied, but the effort to learn (and "effort" was a key concept for Richet, as we shall soon see). For the popular classes and women, it was enough to read a newspaper every day (Richet, 1919a, p.181, 183-184).

\section{Normality and nature}

"The indispensable virtues," Richet (1922a, p.47-48) wrote, "are summed up in one word: normality," by which he meant "the overall average of the type." "The great principle of normality" was the voice of Nature. Wiser than us, she sentenced hideous couplings to sterility. Why, then, persist in prolonging the existence of the abnormal, despite "Nature's order to suppress them?" Instead, "our task is to harden her disdain for the weak, her scorn for the misshapen, her strictness towards abortions." Her course has been "distorted by our social institutions," by which "all normal life has been perverted." Civilisation, "while doing so much for the individual, results in the degradation of the species," and "each time man wishes to alter the laws of animal life (les lois animales), to do better or otherwise than the truly divine Nature, he falls into absurdity." Fortunately, "the normal play of forces will immediately give a legitimate superiority to intelligence, courage, activity, the nobility of soul and body" (Richet, 1919a, p.22, 59-60). So why, one might ask, bother so much about the necessity of human selection? Nor did it occur to Richet that eugenics was the very contrary of letting nature follow its course, since it implied that man should take his own evolution out of Nature's hands and put it into his own. You cannot have your cake and eat it too: either you appeal to Nature as a model, or you try to improve upon her processes on the grounds that they fail in some circumstances. Richet's plea for pitiless eugenics also contradicted what he himself had written on the importance of sympathy in Les bases psychologiques de la morale (Richet, 1907b). There, too, he stated that we should "conform to the state of nature" and "follow the laws of nature," but included "the essential moral precepts" among these. Man, he stated, needs the love of others, and we must be "brotherly and compassionate" and "respect human life." The essential precepts of a morality with "consciousness as its basis and the psychology of pain as its principle" were to "be useful, be righteous, be good." This "threefold ideal" was an "absolute rule" (Richet, 1907b, p.31-32). In his 1892 book on the future, Richet wrote that once science and universal peace had guaranteed the external conditions of wealth and happiness, it would be necessary to "create a superior moral doctrine, something similar to the Christian idea of charity, extended and enlarged" (Richet, 1892, p.249). Later, as we have seen, he viewed civilisation as a cause of degeneration. But in his last book he called upon its defence, describing it as "Christian" as well as "Greco-Roman, Latin, and French." Was this a sign of dynamic, self-critical thinking? 


\section{Races}

There is one point on which Richet was always consistent: his opinion on non-white races. To him, they were just "inferior," and not worth much consideration (Estingoix, 1999). He simply despised them, although he stated he would never hesitate to sacrifice the most beloved of his dogs for the life of a human being, "even ... the lowest of savages" (Richet, 1884, p.421). Unlike "scientific" racists, he never attempted to classify human races, and merely used colours to label them roughly. His racism was as peremptory as any bar-room commonplace. It is true that one or another form of paradigme racial was pervasive across the entire spectrum of French political opinion, particularly between the two World Wars, because of immigration and métissage (Reynaud Paligot, 2007; Frader, 2008; Camiscioli, 2009 , p.2). Even so, to say that Richet's version "took its root in the edge of psychology," particularly the psychologie des peuples (Reynaud Paligot, 2009, p.217), perhaps attributes a veneer of "scientific" dignity to his statements which they simply did not have (and he himself never claimed for them).

Blacks were "all savages" and "barbarians:" "credulous, obscene, frivolous, lazy, mendacious," "half-brethren of monkeys," far inferior to tortoises, squirrels and monkeys on the scale of intelligence, they "dishonour the human species." The Spaniards "did a very good thing" when they destroyed the civilisations they found in Mexico and Peru. "Reds and yellows" were "ferocious and stupid" (among the whites, only the Germans came close); the society of buffaloes or penguins was preferable to that of the yellows, who were "diminutive and ugly" and "never moved beyond semi-barbarism" (Richet, 1919b, p.6-8, 12-13) The fetishism of the "niggers" of Central Africa was simply "foolish:" "a black slave in Mamajombo thinks like the hunting dog that follows his master's gun and whip with his eyes." The Panama Canal must be completed, even if it costs the lives of "thousands of coolies" (Richet, 1884, p.409, 429). "The whole black race has had no function but to produce carbonic acid from the carbon, and urea from the nitrogen of their food." Antelopes had done the same, and "the effect on human progress has been the same." Blacks should certainly be treated with "absolute justice" and "unfailing benevolence," but as for intermarriage, "No, no!" North Americans did well to erect a "moral barrier" to protect the white man, "this masterpiece of nature," from the "black peril" (Richet, 1930, p.158-159). May France have the "grandiose task" of "wresting Africa from barbarism!" (Richet, 1884, p.451). These are just a few instances: if you can imagine any violent and/or ridiculous prejudice about non-white people, you can be sure Richet shared it. Nevertheless, he was not anti-Semitic. Quite to the contrary, he considered the Jews "certainly one of the highest races of mankind;" in a not-so-distant future, they would merge with European populations completely (p.410).

The varieties of intelligence depend substantially on race, Richet (1922a, p.43) said, demonstrated by the fact that the Germans did not have the flexible and quick intelligence of the Italians, and that within France itself the "tiny Flemish" had a heavier and sounder mind than the Provençaux. The French were "the nation endowed with the most refined intelligence" (Richet, 1927, p.52). But despite these differences and Richet's frequent and loose use of the plural in referring to the "white races," for him the man of the future was 
one with the "triumphing European," that is, "the white race, tightly linked:" because of ages of interbreeding, no French or German or Italian race existed, no European peoples were lower than or superior to any other, and "we are all a great homogeneous family" (Richet, 1913, p.80-81; 1935, p.130). In other words: "Blonde or brown hair, blue or black eyes, large or diminutive body, we Europeans are all Aryans, as Gobineau said, and the only difference is language, and above all the will [we have] to belong to one country or another" (Richet, 1935, p.149). Note that these words were published the same year that Hitler enacted the Nuremberg laws. Richet dreamt of the free circulation of people (and trades) in the United States of Europe, with a common currency and a common language (possibly Esperanto; in his 1892 book he considered Volapük), in addition to national ones. But he thought that native languages should be forbidden, and only French (the best of all languages) used in the areas under French hegemony. It was because he loved his country, he said, that he loved the countries of others and that he was an "internationalist" - provided, he specified, that his ideal was not confused with that expressed in the "wicked song of hatred" [the socialist Internationale] and embodied in the "dictators of Moscow" (p.20, 131).

\section{Dream or prediction?}

As hinted above, Richet was hardly ever clear as to what should be done first in order to implement his eugenic ideas. Nor was he always consistent in tone. In some of his post1919 pronouncements he softened the blow, only to resume a ruthless attitude in others. At times he presented his proposals as absolutely and immediately practicable, and sometimes as a "dream," a "fancy," or "a task for our great-grandchildren." He also wavered on what the final object should be. For example, in a 1921 lecture given in Utrecht, he wrote:

Let us not have the immodest pretension of creating a superman (surhomme), a new variety of the human race. For, even were it possible - which is very doubtful - we would risk incurring some great error, some heavy omission which would make this new race scarcely viable, perhaps ridiculous. Let us be more restrained in our wishes. Let us pursue selection while leaving man as he is but choosing among men, that is, picking the best, so as to create not a humankind different from the present one, but a humankind made of the best types of the present human kind (Richet, 1922a, p.40).

Acknowledging that it was "impossible to draw the line beyond which idiocy cannot be tolerated," he left the task to future lawgivers: let us be content, now, with reforming marriage, because "we cannot propose anything effective on the score of selection of intelligence" (Richet, 1922a, p.51, 56). He concluded on a rather low note, after so much insisting on the imminent danger of degeneration. In the same lecture, Richet said he had "often proposed, half-seriously," a premarital test that had "no chance of being adopted:" both young spouses should be obliged to swim across a large river, without any boat ready for rescue. "Too bad for the weak ones carried off by the current!" (p.50). Richet learned to swim when he was almost fifty; one wonders if he might have permitted such a joke (if this is what it was) before that time.

In a 1927 book with the revealing title L'homme impuissant, he spoke as a wise, disenchanted, "stoic and epicurean" old man, inviting readers to be modest without 
despairing, warning them to keep in mind the smallness of the individual and the transient nature of all species, and advising each reader, in Voltaire's words, to "cultivate his garden, however small it may be." He even expressed some misgivings as to the actual growth of man's intelligence in the future, and his fears that it might diminish (Richet, 1927, p.9293, 197). In 1930, he said that once wars had disappeared, diseases had been reduced, death "softened," and science had progressed, there would be one "overwhelming and dominant" concern left: "to make a superior mankind." "Men more handsome, vigorous, resistant to disease, more capable of abstraction, more inventive, happier (maybe?!). Is there any nobler hope? 'Human selection will be the grand work of our descendants'" (Richet, 1930, p.161; emphasis in the original). But three years later, in La grande espérance, Richet (1933a) went as far as to express "reservations" on selection. With a better knowledge of the laws of inheritance and the practice of human selection, he said, "we could 'perhaps' come to create a new human race and change man profoundly." This "progress in human morphology" would take centuries, due to "our unconquerable neophobia." Nevertheless, "the principle of human selection must be one of our great hopes" (Richet, 1933a, p.104; emphasis added). The hope was not "a new human species, more vigorous and long-living," but an increase in the power and extent of intelligence, which would enable us to have a "completely different view of things, less inconsistent and petty than now." There would be no radical change in the constitution of individuals and societies, no transformation in man's thinking, no enlargement of his hopes. In this, Richet admitted, even scientific progress was "powerless" (p.107). But then he qualified these reservations by saying that they only concerned selection "by man." If science was not enough, nature would come to the rescue. So his misgivings (presuming that they were real) were immediately dispelled by invoking Nature, whose beneficent action he had formerly portrayed as obstructed by civilisation.

Even if we are not wise enough to institute human selection, Nature will see to it. She did not wait for our academies, our faculties, our zoological, physiological and botanical laboratories to lead the ancestral monad, from which we derive, to become Galileo, Pascal, Newton, Goethe and Pasteur. She will find some procedure, whether devious or not - I cannot say - by which a higher (supérieure) human race will appear on ... our planet ... The enormous progress of science and the advent of a superior man: this is the future which we are entitled to hope for (Richet, 1933a, p.283, 291).

In his last book, published in the year of his death (1935), Richet used, somewhat inconsistently, the words "chimera," "dream" and "great hope," as well as "my deep, almost prophetic, belief" to depict his idea of a selection "accelerating the evolution of the human species towards an humanité supérieure and of the "creation of a new race, which I would call Superhumanity (Surhumanité)." "The man of the future will be as superior to present man as an academic is today superior to a chimpanzee" (Richet, 1935, p.125-127, 220; in Richet, 1927, p.93, he stated "as a member of the Institut [de France] is superior to a kangaroo or a rhinoceros"). But this would be the task of our great-grandchildren, as the time was not yet ripe, and two conditions needed to be satisfied first: peace all over Europe - where Europe meant "the white race and civilisation," protected against "being perverted by the infusion of less pure blood" - and no limitation on the number of children for married 
couples, since "voluntary, abnormal restriction" was "unhealthy for women and contrary to anything that is respectable: natural law, moral law, the teaching of religions, and patriotic duty" (p.128-129).

\section{Inheritance and effort}

The cornerstone of Richet's eugenics, and of his entire biological philosophy, was his unfaltering belief in the power of inheritance ("inheritance dominates everything," Richet, 1913, p.32) in general, and of the inheritance of acquired characteristics in particular. His work on serotherapy certainly played an important role in this, although it is difficult to say whether it strengthened a pre-existing belief (which we should not forget was common among biologists until the early twentieth century) or if the contrary was true. Experiments seemed to confirm to him that microbes could become so accustomed (s'accoutument) to toxic substances that they withstood huge doses of poison. Consequently, drugs to combat pathogenic microbes became less effective over time and had to be replaced by others. Microbial cells retained a long-term memory (souvenir) of their former transit, however short, through a poisonous environment. This was experimental evidence that "there is an 'inheritance of acquired characteristics'... and that that old and fundamental problem of general biology seems to be definitively solved" (Richet, 1933b, p.110-111; emphasis added).

Richet did not doubt that the same was also true of mental characteristics. These were acquired through "education, habit and exercise," as was particularly evident in the case of intelligence. The will itself was "the result of former habits, of hereditary forces accumulated in the child of a long series of ancestors, and of sensations collected from all sides through the years." It was to these that it owed its "undisputable power." True intelligence was the balance of will and passion: they complement each other and both must be fortified by habit and reflection, in order to "hand down to our children the progress we made on ourselves" (Richet, 1877, p.114, 117).

The general direction of ideas is not left to mere chance. Inheritance, that is to say, the transmission to the newly born of a long series of sensations, reflections and efforts, leads us to one or another form of reasoning, to conceive one thing or another more or less easily. Intelligence is not a blank page where sensation writes whatever it wants. Not at all: man's intelligence has certain nearly irresistible tendencies, and neither education nor instruction can fight against them (Richet, 1898, p.156; cf. 1933a, p.146-147).

The belief that man's intelligence had constantly increased thanks to "both" selection and inheritance of acquired characteristics fitted Richet's bent for both determinism in biological and psychological explanation, and peremptoriness in moral and political prescriptions: "the evolution of intelligence over five hundred million centuries is too gradual and regular to be attributed to chance. It is the result of a loi fatale (Richet, 1935, p.123, 127). Evolution and progress could not be due to a trial-and-error process in a slowly changing environment. "Direct" response by the organism to the demands of the milieu transformateur was a much simpler explanation and a more efficient mechanism. "Inheritance," Richet (1913, p.389) went as far as to say, "is quicker than the environment." 
The key concept of Richet's view of evolution and inheritance of acquired characters, and of much of French Lamarckism (La Vergata, 1998), was effort:

The fundamental law of intellectual inheritance is that what requires a great effort in the father is simplified in the son. Inheritance diminishes personal effort and consequently allows us to move forward. Children, grandsons, and great grandsons of scientists understand things more easily than the children, grandsons, and great grandsons of woodcutters (Richet, 1919a, p.187-188).

Hence the enormous importance of mental exercise, a "gymnastics of the mind:" (Richet, 1919a, p.194) through it "the mind (esprit) becomes more receptive, and this enlarged receptivity is transmitted to descendants," for "the exercise of thinking creates a brain that is capable of thought, and function creates the organ." And as we know, "all functions, all dispositions are transmitted by inheritance" (p.180).

An evidently anthropomorphic term, "effort" made it easy to moralise, as it were, natural processes, and then to draw moral lessons from them. If nature rewarded effort (that is: merit), why shouldn't man do the same? Unfortunately, our absurd way of life means that "half the human population is doomed not to think" (Richet, 1919a, p.130).

Contemporary man no longer makes an individual effort that is the only efficient means of transmitting a higher intelligence to his descendants ... All effort is suppressed by the easiness of modern life ..., which is so comfortable, so easy, and where everything is provided, and all hurdles removed ... Everything 'is at our disposal' ... But annulling individual effort eventually leads to intellectual atrophy (Richet, 1919a, p.180; emphasis in the original).

Incidentally, atrophy, or "brain inertia," was more serious in women, who were "always left out of general civilisation (Richet, 1919a, p.180)." The same was also true of the body, of course: lack of exercise (and its opposite, surménage) could lead to sterility, thereby frustrating the "unconscious effort of Nature, which wants the perpetuation of the race, and to make it strong, healthy, vigorous, and normal" (p.115, 132, 135).

Richet did not share the confidence some of his fellow eugenicists placed in social reforms, such as those proposed by Adolphe Pinard, obstetrician and professor at the Faculté de Medecine, and member of the Eugenics Society. The Lamarckian bent in the Society meant that most of its members believed that changes in the economic, social and hygienic environment would improve the present and future generations (Clark, 1984, p.155-156). But differences in approach and proposals should not be overemphasised, since things were more flexible than our a posteriori distinctions might lead us to suppose (De Luca Barusse, 2009). Believing that the preventive fight against social degeneration was to be given priority over the treatment of its consequences could nourish both attitudes. Both reforms of the social environment and repressive measures were often invoked at the same time to eliminate syphilis, alcoholism, tuberculosis, and other supposedly degenerative diseases, with reputedly "progressive" and "left-of-centre" authors emphasising the need to alleviate the misery of the poor, and "conservatives" putting the defence of the social order first. To quote an extreme case, the "fascist-like" Alexis Carrel suggested in his infamous best-seller Man, the unknown (1935) "an array of public health measures aimed at creating 
the environmental conditions best suited for the development of healthy and toughspirited individuals - such as special diets and exposure to extreme climatic conditions" (Reggiani, 2007, p.69-70). As there was frequent overlapping between pro-natalism and eugenics (especially after First World War), there was also a swinging of the pendulum between confidence in reform and reintegration on the one hand, and a pessimism that translated into the search for forms of exclusion from society on the other (Mucchielli, 2006, p.226). Furthermore, by extending hygiene and puériculture beyond their traditional scope of caring for mothers and children, and introducing what he called "puericulture before procreation" or "puériculture antéconceptionnelle," Pinard himself shifted over time towards eugenics, until he acknowledged (citing Richet) the importance of selection in nature as well as society, and of sterilisation of the "physically and moral degenerate." He coined the word eugennétique to describe the study of degeneration (Pinard, 1912), thereby adding to the rich list of terms available for French students of these issues (viriculture, hominiculture, vénérologie, biosociologie, sociobiologie, sociotechnique, biocratie, eubiose, élevage humain, orthobiose etc.). "Social hygienists" often proved no less drastic than eugenicists in their proposals. Many were inclined to extend to the "defective" the treatment proposed by medical criminologists for "incorrigible criminals:" sterilisation, euthanasia, and the death penalty, and a debate ensued. By the turn of the century, sterilisation (as first suggested in the US) was increasingly considered more humanitarian than death but equally effective (Mucchielli, 2006).

It might seem strange that such a strong believer in the constant progress of science as Richet never discussed August Weismann's experimental rejection of the inheritance of acquired characteristics. He only mentioned it in passing, as if it could be incorporated into his own view without fundamentally altering it (Richet, 1922a, p.37). Nor does Richet ever seem to have taken into account the debates that followed the discovery of Mendel's laws in 1900 and continued for at least a couple of decades. Perhaps he was too busy writing his books to keep up to date. Perhaps he was a victim of the very "cerebral inertia" he denounced in "present-day man." Perhaps he was too fascinated by the moral overtones and implications of the idea of effort. Perhaps it was a mixture of all these factors. There are many examples of scientists not practising what they preach. But let us return to Richet's mixture of Lamarckism and Darwinism, something which, was far from unique to him and common in France (Conry, 1974) and in the so-called "Latin eugenics" (Turda, Gillette, 2014). As late as 1922 he cavalierly affirmed that the two mingled (se confondent) and supported each other: "Lamarckism is the influence transformatrice of the environment. Darwinism is the hereditary transmission of the transformations produced in this way" (Richet, 1922a, p.37). It was as simple as that. But what kind of Darwinism did Richet endorse?

\section{Too "Darwinian" to be a Darwinian}

In On the origin of species Darwin (1859, p.62-63) clearly stated that he used the phrase "struggle for life" "in a large and metaphorical sense." But like many, biologists or otherwise, Richet ignored this qualification and took the phrase at its most narrow literal sense: 
the struggle for life "so masterly expounded by Darwin" was a combat pour l'existence, an "unceasing, relentless, merciless fight" where victory went to "the most able, the best armed, the most numerous," namely the "strongest," that is the "best" - to Richet (1922a, p.54) the survival of the fittest was "the survival of the best" - and where "those that succumb deserve to succumb," as "their inferiority explains, justifies and legitimises their being crushed." He delighted in rhetorical variations on this gruesome theme: a "primordial law dominates nature," by which "the strong annihilate the weak, and the big eat the small;" everywhere "fratricidal struggles, ruthless fights, prey eaten alive, slaughter, massacre, suffering, illness, famine, savage death," "all nature's children rage on each other," and so on. He was so entirely hooked on his own rhetoric, and so engaged in stating that relentless fighting caused "constant progress," that he did not notice that he was contradicting himself when he said that the struggle continues because "nature cares for species, not individuals" (Richet, 1884, p.437-439; 1919b, p.58-59, 60; 1929). If this was the case, how could it be that (as Darwin stated) some variations might develop into new species if they were favoured in the struggle? Nor did Richet allow any place for chance in evolution, as we have seen. His Lamarckianism influenced his reading of Darwin, and effort replaced chance as a source of variation: there was nothing random in evolution, species changed by adapting themselves "directly" and continuously to the environment, with the inheritance of acquired characteristics ensuring the gradual accumulation of the right variations. And this was progress: "each generation is progress on the one which preceded it," "forms and organs become ever more perfect," nature's work "goes on perfecting herself, she is always working towards progressive improvement," "if nature has a goal, this is it" (Richet, 1884, p.442). It was, of course, a "relative, not absolute perfection," since "beings have to conform (se conformer) to the surrounding environment" (p.442; note the Lamarckian tone of the verb). It is revealing that in his lengthiest exposé of the struggle for life, Richet never mentioned natural selection. While many criticised the theory of natural selection for relying too much on the usefulness of selected characteristics, he proved to be more Darwinian than Darwin himself: "No characteristic is useless, and each function has its advantage ... Therefore, all organs, all forms, all functions are but means for fighting." No wonder that, carried away by his own rhetoric, he ended up extolling "Nature's admirable foresight" (Richet, 1884, p.444, 448) - hardly a Darwinian phrase.

By such rhetoric the reader was nudged into complaining that "our civilisations" did their utmost to "ignore and counterpoise the effects of this holy law [of universal struggle]," by allowing all kinds of inferior parents to generate indiscriminately, and that "the admirable mechanism of competition for life (concurrence vitale, the usual French translation of "struggle for existence") was spoiled by the monstrous privileges that human embryos enjoy in their mothers' wombs" (Richet, 1919b, p.59). Richet's conclusion was to "do as Nature does herself" (Richet, 1935, p.123-124).

\section{Final causes}

Richet also managed to find a place for final causes in his hotchpotch LamarckoDarwinism. In 1898 he published an article entitled "L'effort vers la vie et la théorie 
des causes finales" in the Revue Scientifique, of which he was editor (reprinted as Richet, 1902a). After solemnly declaring that, "before daring to speak of a finalite, we should know everything," which is impossible because, "far from it, we know nothing," he characteristically went on to argue that there is a finalité première in nature, "so evident $a$ priori that nobody can dream of denying it." By this, he said, he did not mean anything first metaphysically or in principle, but first in the mere order of appearance to the observer. We do not know why life exists, but we can envisage why such and such forms exist, and give an explanation for them, "whether wrong or not, true or not, whether clever or daring, but in any case passable, of certain details in the organisation or function of beings." In short, we cannot deny that "the eye is made for sight." Moreover, "the adaptation of an organ to its function is so perfect that the inevitable conclusion is that such adaptation is not fortuitous, but intentional (voulue)." "Nature produced no useless organ, everything has a purpose (but)." Therefore, "it is impossible to suppress the theory of final causes in anatomy, zoology, or physiology" (Richet, 1902a, p.4, 6-7, 10-11).

Richet was so intent on expelling chance from the world that he confused law with purpose, efficiency with final causes, and cause with effect. For instance, he did not explain mimetism the way Lamarckians usually did, that is, by the direct action of the environment on the organism, but saw its raison d'être in "the defence of [the] organism." He went a step or two farther: in "those extraordinary and complicated mechanisms, that wonderful harmony," which could not be the effects of chance, he saw "an absolutely firm will, a sort of one-sided decision (comme un partit pris), with a view to achieving a result." Nature "willed" (a voulu) the "perpetual survival of species" - an odd phrase for an evolutionist - and she took all necessary means to that end (Richet, 1902a, p.13).

All this led to the "necessary general conclusion" that, whether individuals or species, "living beings are organised to live." But Richet did not stop here either. He stated that "animated nature presents us with the scene of a living matter that makes an effort towards life (fait effort vers la vie) - in vitam ruens - and, by all possible means, tries to achieve a maximum out of life" (Richet, 1902a, p.18). Here we are: the struggle for life was the "fact," the effort vers la vie the cause, and the cause finale première "life itself." Having made this clarification, Richet gave full rein to his love for repetitious variation: effort immense, amour de la vie, tendance à vivre, "commitment (consigne) that enjoins to resist all causes of destruction thanks to a wonderful correlation of structure to function," "adaptation to life," and obviously, tendance au progrès, for "by the very fact of the struggle for existence, the law of life is one with the law of progress." In short, "the struggle for life produces all that a most wise creator might have produced," and the effort pour la vie is synonymous with finalité immanente (p.19-22). As Conry (1974, p.283-284) aptly noted, such "semantic contamination" was not uncommon among French commentators of Darwin. And one might ask what "adaptation to life" really means.

Richet's essay was reprinted in a book (1902) which included seven essays in the form of letters addressed to him in 1899 by the poet Sully-Prudhomme, who in the meantime had been awarded the Nobel Prize for Literature (1901). The poet proved more sophisticated a thinker than the scientist as he raised matters that Richet had cavalierly skipped over: the danger of anthropomorphism, the distinction between efficient and final causes and 
between mechanism and determinism, the metaphysical character of the concept of a cause finale première, the fact that the observing subject's structure alters objectivity, and the imperfection of many supposedly perfect adaptations (including the eye). He apparently had a better understanding of both Lamarck and Darwin. His first letter started with a serious blow to Richet's meanderings into philosophy by remarking in passing that "Lamarck's theory gave us reason to reject the question of final causes" (Sully-Prudhomme, Richet, 1902, p.26). Richet probably had as little time to answer in detail as we have to deal with Sully-Prudhomme here. Whatever the case, in his second and concluding article he merely restated his views by shamelessly softening the peremptoriness of some of his expressions and making a strategic retreat on a couple of points (which is always possible when one's general ideas are sufficiently vague). He said he never thought of comparing the finalité cosmique to human thinking, and surprisingly noted that he used the term effort "for want of a better one" and in a quite different sense from the psychological one, and that it could be replaced by "progress towards life or tendency to life," which he had done. He added that "imagining that there is perhaps a finalité in living beings cannot entail any rigorous certainty." Even using the concept in "its broadest and haziest sense" (son acception la plus vaste et la plus nuageuse), finalité, which he now qualified as a "hypothesis," had the "immense advantage of preparing for research, directing the experimenter and allowing him to invent and imagine new experiments;" in short, it was "fully justified by experimental results, with no exception" (Richet, 1902b, p.132, 134, 139). "Finalité dominates physiology and general biology" because biologists cannot not dispense with the idea that "all physiological phenomena are useful," they simply cannot reason without it, and are literally "vassals" (inféodés) to it. That "law" (which Richet had just referred to as a "hypothesis") had "never been found to be defective in the study of living beings" (p.136, 141). "The hypothesis of natural selection" - which Richet also calls "a fact - was certainly "admirable," "true and necessary," but "insufficient." It by no means explained the development of intelligence and consciousness, nor "that tendency to a source of a more intense life, that resistance to destruction, that perpetual and fiery struggle of which all terrestrial life is the result." It said nothing about the "secret springs" that compel organisms to struggle with each other. We must go beyond selection if we want to explain what Darwin and his followers could account for only by "torturing and denaturing the data of observation and experiment" (p.137-138). Mechanism did rule the world, but it explained nothing, and was just "a statement of fact." Only "the hypothesis [no longer a law?] of an effort towards a maximum and optimum of life is acceptable." It gave us a better understanding of "the deep sense of life, the evolution towards a better state, namely, progress, the biological one first, then the moral one, which is related to it" (p.140-141).

\section{Final considerations}

Yes, Richet did indeed speak too much, and in his non-experimental work he seldom said anything original. Most of his work boils down to an unrestrained flow of personal utterances, more than a few of which are simply educated versions of the sort of conversation you can hear in any bar. He showed a tiresome tendency to repeat himself, with merely 
rhetorical variations or with genuine contradictions. In other words, as one of my students not well versed in the niceties of academic language might put it, he was a pompous windbag, a muddler affected by logorrhea, and a repetitive bungler.

In spite of all this, his case is interesting from a historical as well as general point of view. It shows that it was possible to simultaneously be many things that today (with the benefit of hindsight) might seem incompatible: a Lamarckian and a Darwinian, a racist and a "humanitarian," a pro-natalist and a eugenicist, a pacifist and a nationalist, an experimentalist and a supporter of final causes, an apostle of science and a believer in spiritualism. His personality was certainly special, and "in many ways he was not typical" as a eugenicist (Schneider, 2002, p.114). His practical proposals met with a mixed reception, which may be why the way he presented them fluctuated over time. Sterilisation and euthanasia were far from generally accepted, although they were supported by a larger number of doctors and social hygienists than is generally imagined, even in pre-Vichy France (Carol, 1995, p.163-187). Historians have documented convergences as well as divergences, in Europe generally and in France in particular, between pro-natalism and eugenicism, and the presence of figures representing different political opinions in each of them. As was his habit, Richet saw no contradiction. He dispelled any shadow of it as early as La sélection humaine. Dénatalité? "In the near future it is excess rather than scarcity that is to be feared," he said, cavalierly ignoring his fellow countrymen's anxiety (Richet, 1919a, p.166-167). And whatever the case, quality was more important than quantity, he added. Et voilà.

Richet's eugenics was "more in tune with the new conditions of the 1930s" (Schneider, 2002, p.194), when there was "a convergence of two ostensibly diametrically opposed phenomena: eugenics and pro-natalism" (Read, 2012, p.373, 379). But the grounds for this rapprochement lay in the 1920s, when "on the left, an influential minority of eugenicists, emerging in part from the neo-Malthusian tradition, became convinced of the need for France to promote both racial hygiene and fecundity ... and allied itself with the pronatalist camp." Moreover, "the French Eugenics Society counted prominent men of both the centre-right and the centre-left among its ranks," as well as many socialists among its first adherents (Read, 2012, p.379). However, after 1935, the year Richet died, it was Alexis Carrel, the 1912 Nobel laureate for medicine, who set the stage for a renewed debate on drastic means of dealing with the unfit thanks to the enormous international success of Man, the unknown, published that year (Mucchielli, 1997; Reggiani, 2007). Carrel's association with the Vichy regime and the extreme right wing did the rest. Despite the many affinities between the two (including an interest in telepathy and psychic phenomena, but first and foremost a tendency to pronounce on literally everything), Carrel did not mention Richet in his masterpiece of irrational, hotchpotch scientism, and Richet only referred to "mon ami Carrel" in passing in his last book. I do not believe it is an exaggeration to state that after the early 1920s Richet survived by rehashing his views some way or another and by an imitation of himself.

Richet is only a particularly striking instance of something that is normal in the history of science, and of ideas in general: it possible to be an important scientist and still pronounce nonsense in the name of science. But that nonsense is part of history, and the 
historian must take it seriously. Science does not per se protect scientists from themselves. Luckily, it is self-correcting in the long run, despite the sad fact that scientists often are not.

\section{NOTES}

\footnotetext{
${ }^{1}$ In this and other citations of texts from non-English languages, a free translation has been provided.

${ }^{2}$ In the original: "La science et la paix, c'est le Bonheur."

${ }^{3}$ In the original: "an amour désordonné du combat."

${ }^{4}$ In the original: “Toute la race nègre n'a eu jusqu'à présent d'autre fonction que de faire de l'acide carbonique avec le carbone et de l'urée avec l'azote de ses aliments."
}

\section{REFERENCES}

BÉJIN, André.

Richet, Charles. In: Tort, Patrick (Org.).

Dictionnaire du darwinisme et de l'évolution, v.3. Paris: Presses Universitaires de France. p.36913694. 1996.

BÉJIN, André.

Les trois phases de l'évolution du darwinisme social en France. In: Tort, Patrick (Ed.).

Darwinisme et société. Paris: Presses Universitaires de France. p.353-361. 1992.

BÉJIN, André.

La fondation de l'Alliance Nationale. Population et Avenir, v.45, n.597, p.17-18. 1990.

BELLOMY, Donald C.

"Social Darwinism" revisited. Perspectives in American History. v.1, p.1-129. 1984.

BERNARDINI, Jean-Marc.

Le darwinisme social en France (1859-1918): fascination et rejet d'une idéologie. Paris: CNRS Éditions. 1997.

CAMISCIOLI, Elisa.

Reproducing the French race: immigration, intimacy, and embodiment in the early twentieth century. Durham: Duke University Press. 2009.

CAROL, Anne.

Histoire de l'eugénisme en France. Paris: Seuil. 1995.

CLARK, Linda L.

Social Darwinism in France. Alabama: The

University of Alabama Press. 1984.

CONRY, Yvette.

L'introduction du darwinisme en France au XIXe siècle. Paris: Vrin. 1974.

CROOK, Paul.

Darwinism, war and history: the debate over the biology of war from the "Origin of Species" to the First World War. Cambridge: Cambridge University Press. 1994.
DARWIN, Charles.

On the origin of species by means of natural selection, or the preservation of favoured races in the struggle for life. London: John Murray. 1859.

DE LUCA BARUSSE, Virginie.

Pro-natalism and hygienism in France, 1900-1940: the example of the fight against venereal disease. Population, v.64, n.3, p.477506. 2009.

DROUARD, Alain.

Eugenics in France and in Scandinavia: two case studies. In: Robert A. Peel (Ed.). Essays in the history of eugenics. London: The Galton Institute. p.173-208. 1998.

ESTINGOIX, Pierrette.

Race, peuple et evolution dans l'oeuvre de C. Richet (1850-1935). In: Kail, Michel; Vermès, Geneviève (Org.). La psychologie des peuples et ses dérives. Paris: CNDP. p.109-122. 1999.

FRADER, Laura.

Breadwinners and citizens: gender in the making of the French social model. Durham, NC: Duke University Press. 2008.

KOOS, Cheryl A.

Gender, the family, and the fascist temptation: visions of masculinity in the natalist-familiarist movement, 1922-1940. In: Kalman, Samuel; Kennedy, Sean (Ed.). The French right between the wars: political and intellectual movements from conservatism to fascism. New York: Berghahn. p.112-126. 2014.

\section{KOOS, Cheryl A.}

The good, the bad, and the childless: the politics of female identity in Maternité (1929) and La Maternelle (1933). Historical Reflections/Réflexions historiques, v.35, n.2, p.3-20. 2009.

KOOS, Cheryl A.

Gender, anti-individualism and nationalism: the Alliance Nationale and the pronatalist backlash 
against the Femme Moderne, 1933-1940. French Historical Studies, v.19, n.3, p.699-723. 1996.

LA VERGATA, Antonello.

Pacifismo eugenetico. In: Carlo Altini (Org.). Guerra e pace: storia e teoria di un'esperienza politica. Bologna: Il Mulino. p.215-241. 2015a.

LA VERGATA, Antonello. Paz por el bien de la raza. In: Redondo, Francisco A. González (Ed.). Ciencia y técnica entre la paz y la guerra: 1714, 1814, 1914. Madrid: Sociedad Española de Historia de las Ciencias y de la Técnica. v.2, p.1059-1065. 2015b.

LA VERGATA, Antonello.

Néolamarckisme et éthique. In: Congrès

National des Sociétés Historiques et

Scientifiques, 119., 1994, Amiens. Actes... Paris: Editions du CTHS. p.695-703. 1998.

LE BON, Gustave.

Les premières civilisations. Paris: Marpont et Flammarion. 1889.

MUCCHIELLI, Laurent.

Criminology, hygienism, and eugenics in France, 1870-1914: the medical debates on the elimination of "incorregible". In: Becker, Peter; Wetzell, Richard F. (Ed.). Criminals and their scientists: the history of criminology in international perspective. Washington: German Historical Institute; Cambridge: Cambridge University Press. p.207-229. 2006.

MUCCHIELLI, Laurent.

Utopie élitiste et mythe biologique: l'eugénisme d'Alexis Carrel. Paris: Esprit. 1997.

OSTY, Eugène.

Charles Richet (1850-1935). Paris: Institut

Métapsychique International. 1936.

PINARD, Adolphe.

De l'eugennétique. Bulletin Médical, v.26, p.11231127. 1912.

READ, Geoff.

Was there a fascist femininity? Gender and French fascism in political context. In: Kalman, Samuel; Kennedy, Sean (Ed.). The French right between the wars: political and intellectual movements from conservatism to fascism. New York: Berghahn. p.127-140. 2014a.

READ, Geoff.

The republic of men: gender and the political parties in interwar France. Oxford: Berghahn. 2014b.

READ, Geoff.

"Citizens useful to their country and to humanity": the convergence of eugenics and pro-natalism in interwar French politics, 19181940. Canadian Bulletin of Medical History/
Bulletin Canadien d'Histoire Médicale, v.29, n.5, p.373-397. 2012.

READ, Geoff.

Des hommes et des citoyens: paternalism and masculinity on the Republican right in interwar France, 1919-1939. Historical Reflections/ Réflexions historiques, v.34, n.2, p.88-111. 2008.

REGGIANI, Andrés Horacio.

God's eugenicist: Alexis Carrel and the sociology of decline. Oxford: Berghahn. 2007.

REYNAUD PALIGOT, Carole.

La République racial: paradigme racial et idéologie républicaine (1860-1930). Paris: Presses Universitaires de France. 2009.

REYNAUD PALIGOT, Carole.

Races, racisme et antiracism dans les années 1930. Paris: Presses Universitaires de France. 2007.

RICHET, Charles.

Au secours! Paris: Peyronnet. 1935.

RICHET, Charles.

La grande espérance. Paris: Montaigne. 1933a.

RICHET, Charles.

Souvenirs d'un physiologiste. Paris: Peyronnet. 1933b.

RICHET, Charles.

L'avenir et la prémonition. Paris: Aubier. 1931.

RICHET, Charles.

L'âge d'or et l'âge de l'or. Paris: Aubier. 1930.

RICHET, Charles.

Apologie de la biologie. Paris: Doin. 1929.

RICHET, Charles.

Notre sixième sens. Paris: Montaigne. 1928.

RICHET, Charles.

L'homme impuissant. Paris: Aubier-Montaigne. 1927.

RICHET, Charles.

Le savant. Paris: Hachette. 1923.

RICHET, Charles.

La selection humaine. In: Apert, Eugène et al. Eugénique et sélection. Paris: Alcan. p.33-57. 1922a.

RICHET, Charles.

Traité de métapsychique. Paris: Alcan. 1922b.

RICHET, Charles.

La sélection humaine. Paris: Alcan. 1919a.

RICHET, Charles.

Pour la paix. Paris: Ficker. 1919b.

RICHET, Charles.

L'homme stupide. Paris: Flammarion. 1919c. 
RICHET, Charles.

Les coupables. Paris: Flammarion. 1916.

RICHET, Charles.

L'avenir de la paix et la réalité de la guerre. Paris: Société Française pour l'Arbitrage entre les Nations. 1913.

RICHET, Charles.

Le passé de la guerre et l'avenir de la paix. Paris: Société d'Éditions Littéraires et Artistiques. 1907a.

\section{RICHET, Charles.}

Les bases psychologiques de la morale. Bulletin de l'Institut Général Psychologique, v.7, n.1-2. 1907b.

RICHET, Charles.

La guerre et la paix. Paris: Cahiers de la Quinzaine. 1905.

RICHET, Charles.

L'effort vers la vie et la théorie des causes finales. In: Armand Sully-Prudhomme; Charles Richet. Le problème des causes finales. Paris: Alcan. p.124. 1902a.

RICHET, Charles.

L'effort vers la vie et les causes finales. In: Armand Sully-Prudhomme; Charles Richet. Le problème des causes finales. Paris: Alcan. p.131141. $1902 \mathrm{~b}$.

RICHET, Charles.

Exposé des travaux scientifiques de M. Charles Richet. Paris: Typographie Chamerot et Renouard. 1901.

RICHET, Charles.

Les guerres et la paix: étude sur l'arbitrage international. Paris: Librairie C. Reinwald, Schleicher Frères. 1899.

RICHET, Charles.

Essai de psychologie générale. Paris: Alcan. 1898.

RICHET, Charles.

La guerre et la civilisation: réponse à M. Le Bon. Revue Scientifique, v.1, p.204-206. 1894.

RICHET, Charles.

Dans cent ans. Paris: Ollendorf. 1892.

RICHET, Charles.

La dépopulation de la France. Revue Scientifique, v.47, n.5, p.145-146. 1891.
RICHET, Charles.

L'homme et l'intelligence. Paris: Alcan. 1884.

RICHET, Charles.

Les poisons de l'intelligence. Paris: Ollendorff.

(Orig. Revue des Deux Mondes). 1877.

RONSIN, Francis.

La grève des ventres: propagande néo-

malthusienne et baisse de la natalité en France, 19e-20e siècles. Paris: Aubier. 1980.

SCHNEIDER, William H.

Quality and quantity: the quest for biological regeneration in twentieth-century France.

Cambridge: Cambridge University Press. 2002.

SCHNEIDER, William $\mathrm{H}$.

The eugenics movement in France, 1890-1940.

In: Adams, Mark (Ed.). The wellborn science:

eugenics in Germany, France, Brazil, and Russia.

Oxford: Oxford University Press. p.69-109. 1990.

SCHNEIDER, William $\mathrm{H}$.

Puericulture and the style of French eugenics.

History and Philosophy of the Life Sciences, v.8, n.2, p.265-277. 1986.

SCHNEIDER, William $\mathrm{H}$.

Toward the improvement of the human race: the history of eugenics in France. Journal of Modern History, v.54, n.2, p.268-291. 1982.

SULLY-PRUDHOMME, Armand; RICHET, Charles.

Le problème des causes finales. Paris: Alcan. 1902.

TURDA, Marius.

The biology of war: eugenics in Hungary, 19141918. Austrian History Yearbook, v.40, p.238-264. 2009.

TURDA, Marius; GILLETTE, Aaron.

Latin eugenics in comparative perspective. London: Bloomsbury. 2014.

VOM BROCKE, Berhard.

Wissenschaft versus Militarismus: Nicolai, Einstein und die "Biologie des Krieges". Annali dell'Istituto Italo-Tedesco di Trento/Jahrbuch des italienisch-deutschen historisches Institut in Trient, v.10, p.405-508. 1984.

WOLF, Stewart.

Brain, mind, and medicine: Charles Richet and the origins of physiological psychology. Piscataway: Transaction Publishers. 2002.

\section{$\rightarrow \rightarrow \rightarrow<<<$}

